Pendas: Primary Education Journal

Volume 2 Nomor 1, Januari - Juni 2021

P-ISSN: 2686-5130 || E-ISSN : 2776-298X

Availabel online at: https://journal.unram.ac.id/index.php/pendas

\title{
STANDAR ISI, BAHASA, DAN PENYAJIAN BUKU TEMATIK TERBITAN \\ KEMENTERIAN PENDIDIKAN DAN KEBUDAYAAN (2017) TEMA 2 "UDARA BERSIH BAGI KESEHATAN" KELAS V KURIKULUM 2013
}

\author{
Halimatussa'diah ${ }^{1),}$ Sudirman $^{2),}$ Heri Setiawan ${ }^{3)}$ \\ ${ }^{1,2,3}$ Pendidikan Guru Sekolah Dasar, FKIP - Universitas Mataram \\ *Corresponding Author: diahhalimatussa227@gmail.com
}

\begin{tabular}{l}
\hline ARTICLE INFO \\
\hline Article history \\
Received : January $8^{\text {th }}, 2021$ \\
Revised : March $9^{\text {th }}, 2021$ \\
Accepted :May $21^{\text {th }}, 2021$ \\
Keywords: \\
Standard content, language, and \\
presentation, Thematic books
\end{tabular}

ABSTRACT

Books are one of the learning resources as well as important teaching materials and are widely used in learning. Presentation of material in textbooks must meet predetermined standards. Currently, many writers are competing to publish textbooks without paying attention to the standards in writing and persentation of textbooks. Of course this can be a source of problems in learning. This study aims to determine the suitability of content, language, and presentation standards in the thematic monks published by the ministry of education and culture (2017) theme 2 class V curriculum 2013. The approach used in this study is a qualitative approach that specifiallt uses content analysis type research. Data collection techniques using documentary studies. Data analysis used interactive model data analysis from Miles \& Huberman. The result showed that the suitability of thematic books published by the ministry of education and culture (2017) theme 2 class V curriculum 2013 seen from the content, language and presentation standards were obtaianed : 1) conformity to content standards was $93,05 \%$ or in very suitable category; 2) conformity to language standards was $93,32 \%$ or in very suitable category; 3) conformity to standards of presentation was $100 \%$ or in very suitable category.

ABSTRAK Buku merupakan salah satu sumber belajar sekaligus bahan ajar yang penting dan banyak digunakan dalam pembelajaran. Penyajian materi dalam buku teks harus memenuhi standar yang sudah ditentukan. Saat ini banyak para penulis yang berlomba-lomba menerbitkan buku teks tanpa memperhatikan standar dalam penulisan dan penyajian buku teks. Tentunya hal ini dapat menjadi salah satu sumber masalah dalam pembelajaran. Penelitian ini bertujuan untuk mengetahui kesesuaian standar isi, bahasa, dan penyajian pada buku tematik terbitan Kementerian Pendidikan dan Kebudayaan (2017) tema 2 kelas V kurikulum 2013. Pendekatan yang digunakan dalam penelitian ini adalah pendekatan kualitatif yang secara spesifik menggunakan penelitian jenis analisis isi. Teknik pengumpulan data menggunakan studi dokumenter. Analisis data menggunakan analisis data model interaktif dari Miles \& Huberman. Hasil penelitian menunjukkan bahwa kesesuaian buku tematik terbitan Kementerian Pendidikan dan Kebudayaan (2017) tema 2 kelas V kurikulum 2013 dilihat dari standar isi, bahasa dan penyajian didapatkan : (1) kesesuaian pada standar isi adalah sebesar $93,05 \%$ atau pada kategori sangat sesuai; (2) kesesuaian pada standar bahasa sebesar $93,32 \%$ atau pada kategori sangat sesuai; dan (3) kesesuaian pada standar penyajian sebesar $100 \%$ atau pada kategori sangat sesuai.. 


\section{A. PENDAHULUAN}

Buku merupakan salah satu sumber belajar sekaligus bahan ajar yang penting dan banyak digunakan dalam pembelajaran. Hal ini dikarenakan penggunaan buku yang tidak dibatasi waktu, tempat, maupun usia pengguna namun tetap ada ketentuan dalam penyusunan maupun penggunaannya. Oleh karena itu buku teks haruslah sempurna dari berbagai aspek dalam penyajian materi yang akan dijadikan sebagai sumber pembelajaran bagi masyarakat, khususnya siswa dan guru.

Penyajian materi dalam buku teks harus memenuhi standar yang sudah ditentukan. Menurut BSNP 2017 (Badan Standar Nasional Pendidikan) penyajian materi yang baik hendaklah menempatkan siswa sebagai subjek pembelajaran yang berorientasi pada aktivitas ilmiah, saintifik, kerja sama, penemuan, dan pemecahan masalah. Selain itu juga penyajian materi hendaklah merangsang siswa untuk berfikir kreatif tentang apa, mengapa dan bagaimana mempelajari materi untuk mengembangkan kompetensi sikap spiritual dan sikap sosial. Standar atau kriteria yang harus diperhatikan dalam penyusunan buku teks yaitu standar isi, bahasa dan penyajian.

Standar isi yang dimaksud berupa kelengkapan dan keluasan materi dengan KD dan KI, Kedalaman materi sesuai dengan KD dan KI, keakuratan konsep dan definisi, keakuratan fakta dan data, keakuratan contoh dan istilah, serta keakuratan gambar, diagram dan ilustrasi. Standar bahasa yang meliputi kesesuaian dengan tingkat perkembangan intelektual, sosial dan emosional, bahasa yang komunikatif, bahasa yang digunakan memiliki keruntutan dan keterpaduan, kesesuaian ejaan dan tanda baca, serta bahasa yang dialogis dan interaktif. Sedangkan standar penyajian yang meliputi kelengkapan sajian dalam tiap pembelajaran, penyajian materi, dan penyajian pembelajaran.

Saat ini, banyak para penulis yang berlomba-lomba menerbitkan buku teks tanpa memperhatikan aturan-aturan dan kriteria standar dalam penulisan dan penyajiann buku teks. Banyaknya buku teks yang beredar tentu memiliki karakteristik yang berbeda serta tidak menutup kemungkinan terdapat beragam pula buku yang tidak sesuai standar baik dari segi isi, bahasa dan penyajian materi. Seperti apapun buku itu, hendaklah sesuai standar berupa standar isi, bahasa dan penyajian.

Berdasarkan hasil wawancara yang dilakukan pada 29 Juni 2020 dengan guru kelas V SDN 1 Labuhan Haji ditemukan bahwa dalam memilih buku yang akan digunakan siswa dalam proses pembelajaran, guru tidak pernah melakukan pengkajian terlebih dahulu terhadap buku sebelum diberikan kepada siswa. Tentunya hal ini dapat menjadi sumber masalah dalam pembelajaran yang pada akhirnya siswa yang menjadi korban. Dimana buku yang tidak sesuai standar dapat menyebabkan kegagalan dalam menarik minat siswa untuk belajar yang berimbas pada motivasi dan prestasi belajar siswa. Untuk membantu guru agar dapat memilih buku teks yang tepat dalam hal ini buku tematik kurikulum 2013 maka perlu dilakukan analisis buku teks dilihat dari segi standar isi, bahasa dan penyajian. Bagaimana buku yang baik dari ketiga kriteria ini menjadi bahan yang menarik untuk dikaji. Penelitian ini dinilai penting untuk dilaksanakan karena dengan adanya penelitian ini diharapkan dapat dijadikan referensi bagi para guru dalam memilih dan menilai buku ajar yang baik untuk digunakan oleh siswa dalam pembelajaran. Berdasarkan hal tersebut maka tujuan penelitian ini adalah untuk menganalisis kesesuaian standar isi, bahasa, dan penyajian pada 
buku tematik terbitan Kementerian Pendidikan dan Kebudayaan (2017) tema 2 udara bersih bagi kesehatan kelas V kurikulum 2013.

\section{B. METODE PENELITIAN}

Metode pendekatan penelitian menggunakan pendekatan kualitatif yang secara spesifik menggunakan penelitian jenis analisis isi (content analysis). Menurut Fraenkel dan Wallen (2006:483) analisis isi merupakan suatu teknik yang memungkinkan seseorang menguraiakan dan memahami perilaku manusia secara tidak langsung dengan menganalisis komunikasi antara satu manusia dengan manusia lainnya dalam berbagai genre dan ragam bahasa yang digunakan. Penelitian ini menganalisis buku tematik siswa terbitan kementerian pendidikan dan kebudayaan (2017) tema 2 kelas V kurikulum 2013. Data dalam penelitian ini termasuk dalam kategori paper yaitu sumber data yang menyajikan tanda-tanda berupa huruf, angka, gambar, atau simbol-simbol lain (Arikunto,2010:172). Sumber data dalam penelitian ini berupa buku teks siswa kelas V SD/MI tema 2 Udara Bersih bagi Kesehatan Kurikulum 2013 terbitan Kemendikbud. Metode pengumpulan data yang digunakan adalah studi dokumenter. Sedangkan instrumen penelitian ini yakni peneliti itu sendiri dibantu instrumen penelitian. Metode analisis data menggunakan teknik analisis data model interaktif dari Miles dan Huberman.

\section{HASIL DAN PEMBAHASAN}

Berdasarkan hasil wawancara yang dilakukan pada 29 Juni 2020 dengan guru kelas V SDN 1 Labuhan Haji ditemukan bahwa dalam memilih buku yang akan digunakan siswa dalam proses pembelajaran, guru tidak pernah melakukan pengkajian terlebih dahulu terhadap buku sebelum diberikan kepada siswa.

Pengkajian terlebih dahulu terhadap buku sebelum diberikan kepada siswa merupakan hal penting yang harus dilakukan oleh guru. Dimana buku yang tidak sesuai standar dapat menyebabkan kegagalan dalam menarik minat siswa untuk belajar yang berimbas pada motivasi dan prestasi belajar siswa. Berikut hasil analisis buku teks pada masing-masing standar penilaian yang ada.

\section{1.) Standar Isi}

Aspek standar isi terdiri atas enam indikator penilaian. Indikator kelengkapan dan keluasan materi dengan KD dan KI memperoleh jumlah skor 10, indikator kedalaman materi sesuai dengan KD dan KI memperoleh skor 9, indikator keakuratan konsep dan definisi memperoleh skor 12, indikator keakuratan fakta dan data memperoleh skor 12 , indikator keakuratan contoh dan istilah memperoleh skor 12, sedangkan indikator keakuratan gambar, diagram dan ilustrasi memperoleh skor 12. Jumlah skor pada aspek ini adalah 67. Sedangkan skor maksimal dalam aspek ini yaitu 72. Maka persentase yang diperoleh pada aspek ini adalah 93,05\% dan termasuk dalam kriteria sangat sesuai.

2.) Standar Bahasa

Aspek standar bahasa terdiri atas lima indikator penilaian. Indikator kesesuaian dengan tingkat perkembangan intelektual, sosial dan emosional memperoleh skor 12, indikator pemakaian bahasa yang komunikatif memperoleh skor 10, indikator pemakaian bahasa memiliki keruntutan dan keterpaduan alur berfikir memperoleh skor 12, indikator kesesuaian ejaan dan tanda baca memperoleh skor 10, serta indikator bahasa dialogis dan 
interaktif memperoleh skor 12. Jumlah skor yang didapatkan pada aspek ini adalah 56. Sedangkan skor maksimal yang harus diperoleh pada aspek ini yaitu 60. Maka persentase pada aspek ini sebesar 93,32\% yang termasuk dalam kategori sangat sesuai.

3.) Standar Penyajian

Aspek standar penyajian terdiri atas 3 indikator penilaian. Indikator teknik penyajian memperoleh skor 12 , indikator penyajian materi memperoleh skor 12 , serta indikator penyajian pembelajaran memperoleh skor 12. Jumlah skor pada aspek ini memperoleh skor 36 yang merupakan skor maksimal dalam aspek penyajian, sehingga persentase yang diperoleh pada aspek ini yaitu mencapai $100 \%$ yang termasuk dalam kategori sangat sesuai.

\section{Pembahasan}

Berdasarkan hasil penelitian yang telah dipaparkan diatas, diperoleh persentase skor penilaian buku tematik siswa terbitan kemendikbud (2017) tema 2 kelas V kurikulum 2013 dilihat dari standar isi, bahasa dan penyajian. Pembahasan mengenai hasil analisis buku teks tersebut sebagai berikut.

\section{1.) Standar Isi}

Aspek standar isi memperoleh persentasi skor 93,05\% dengan kategori sangat sesuai. pada indikator kelengkapan dan keluasan materi dengan KD dan KI sudah sangat sesuai dan memiliki kelengkapan dan keluasan sesuai dengan KD dan KI yang ada. Sedangkan pada 2 subtema lainnya, memperoleh skor 3 yang artinya termasuk dalam kategori sesuai namun masih terdapat beberapa pembelajaran yang belum memuat semua materi pokok bahasan dalam aspek ruang lingkup yang mendukung tercapainya KD pada semua KI yang ada serta masih belum terdapat contoh yang bervariasi. Pada indikator kedalaman materi sesuai dengan $\mathrm{KD}$ dan KI sudah memuat dimensi pengetahuan faktual yang mendukung pencapaian KD pada setiap KI semua subtema sudah memuat dimensi pengetahuan konseptual yang mendukung pencapaian KD pada setiap KI namun beberapa pembelajaran dalam masing-masing subtema belum memuat dimensi pengetahuan prosedural yang mendukung pencapaian KD pada setiap KI. Pada Indikator keakuratan konsep dan definisi sudah tidak terdapat kesalahan dalam penulisan konsep dan definisi. Pada Indikator keakuratan fakta dan data semua subtema tidak terdapat kesalahan dalam penulisan fakta dan data. Pada indikator keakuratan contoh dan istilah semua subtema tidak terdapat kesalahan dalam penulisan contoh/kasus dan istilah. Pada indikator keakuratan gambar, diagram, dan ilustrasi semua subtema tidak terdapat kesalahan dalam penulisan gambar, diagram, dan ilustrasi. Sehingga secara keseluruhan pada aspek standar isi buku tematik siswa terbitan kemendikbud (2017) tema 2 kelas V sudah sangat sesuai, meskipun masih terdapat beberapa kekurangan.

\section{2.) Standar Bahasa}

Aspek standar bahasa memperoleh persentasi skor 93,32 \% dengan kategori sangat sesuai. Pada indikator kesesuaian dengan tingkat perkembangan intelektual, sosial dan emosional semua subtema pada buku teks sudah menggunakan bahasa yang secara imajinatif dapat dibayangkan oleh siswa, bahasa yang digunakan juga dapat menggambarkan konsep-konsep mulai dari lingkungan umum hingga lingkungan terdekat, serta bahasa yang digunakan mudah dipahami siswa. Pada indikator pemakaian bahasa yang komunikatif hanya subtema 2 yang memperoleh skor 4 yang artinya materi yang ada pada buku teks sudah sangat sesuai dan menggunakan bahasa yang komunikatif dimana 
sudah memiliki keterbacaan pesan dalam buku teks, memiliki ketepatan kaidah bahasa serta ketepatan penulisan kata. Sedangkan pada subtema 1 dan 3, memperoleh skor 3 yang artinya termasuk dalam kategori sesuai namun masih terdapat beberapa pembelajaran yang masih memiliki banyak kesalahan dalam penulisan kaidah bahasa dan penulisan kata. Pada indikator pemakaian bahasa memiliki keruntutan dan keterpaduan alur berfikir semua subtema pada buku teks sudah memiliki penyampaian pesan antara pembelajaran 1 dengan yang lain mencerminkan hubungan yang logis, penyampaian pesan antar kalimat dalam paragraf mencerminkan hubungan yang logis atau masuk akal, serta penyusunan kata-kata dalam kalimat mencerminkan hubungan yang logis atau masuk akal. Pada indikator kesesuaian ejaan dan tanda baca semua sub tema tidak terdapat sama sekali kesalahan dalam penulisan ejaan dan tanda baca. Sedangkan pada indikator bahasa dialogis dan interaktif semua subtema pada buku teks sudah menggunakan bahasa mengandung interaksi timbal balik secara tidak langsung (terdapat kalimat pertanyaan untuk siswa), bahasa yang digunakan dapat mendorong siswa untuk mempelajarinya secara tuntas, serta bahasa yang digunakan mampu merangsang siswa untuk bertanya dan mencari jawaban sendiri dari sumber lain. Sehingga secara keseluruhan pada aspek standar bahasa buku tematik siswa terbitan kemendikbud (2017) tema 2 kelas V sudah sangat sesuai meskipun masih terdapat beberapa kekurangan.

\section{3.) Standar Penyajian}

Aspek standar penyajian memperoleh perrsentasi 100\% dengan kategori sangat sesuai. Pada indikator teknik penyajian semua subtema pada buku teks sudah sangat sesuai dan mengandung kalimat pembangkit motivasi pada setiap pembelajaran, mengandung kalimat pendahuluan dan penutup pada setiap pembelajaran, serta memiliki contoh-contoh soal dalam setiap pembelajaran. Pada indikator penyajian materi semua subtema pada buku teks sudah sangat sesuai dan penyajian materi disajikan dari yang sederhana ke kompleks, materi pada bagian sebelumnya bisa membantu pemahaman materi pada bagian selanjutnya, serta materi yang disajikan runtut antar pembelajaran satu dengan yang lain. Pada indikator penyajian pembelajaran semua subtema pada buku teks sudah sangat sesuai dan penyajian pembelajaran sudah mengutamakan keterlibatan siswa, penyajian pembelajaran runtut antar pembelajaran satu dengan yang lain, serta keberadaan materi pada tiap pembelajaran sesuai dengan subtema.

Secara keseluruhan dari ketiga aspek standar yang dinilai yaitu standar isi, bahasa, dan penyajian, buku tematik siswa kelas V Tema 2 Udara Bersih bagi Kesehatan terbitan Kementerian Pendidikan dan Kebudayaan (2017) sudah termasuk dalam kategori sangat layak. Hanya beberapa indikator saja yang masih kurang yaitu pertama pada standar isi, kekurangannya pada kesesuaian isi materi dengan KD dan KI yang ada. Dimana masih banyak pembelajaran yang materinya belum mencakup seluruh KD yang telah dipaparkan dalam buku guru, misalnya pada pembelajaran 4 subtema 1 . Pada buku guru, pembelajaran 4 sberisi KD IPS,PPKn,dan BI, namun pada buku siswa, materi yang dicantumkan hanya mengenai KD IPS saja. Selain itu juga, pada buku siswa, masih kekurangan contoh yang bervariasi, sehingga guru harus menambahkan sendiri contoh-contoh yang sesuai dengan lingkungan keseharian siswa.

Kedua pada standar bahasa, kekurangannya terdapat pada indikator pemakaian bahasa yang komunikatif dan kesesuaian ejaan dan tanda baca. Dimana pada buku siswa kelas 
Tema 2 Udara Bersih bagi Kesehatan ini ditemukan masih banyak kesalahan dalam penggunaan kaidah bahasa, kesalahan dalam penulisan kata, serta kesalahan dalam ejaan dan tanda baca. Misalnya pada pembelajaran 1 subtema 1, dimana masih terdapat banyak kesalahan dalam penggunaan kaidah bahasa serta kesalahan dalam penulisan kata. Selain itu juga pada pembelajaran 5 subtema 3 juga terdapat kesalahan peletakkan tanda baca.

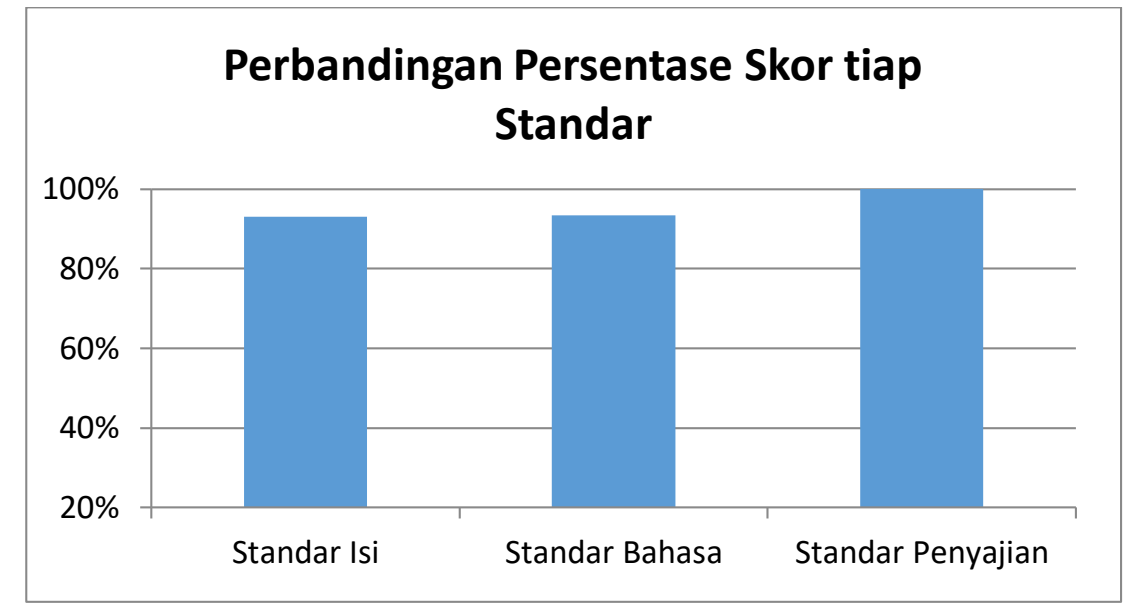

Gambar 5.15 Perbandingan persentase skor tiap standar

\section{PENUTUP}

\section{Simpulan}

Berdasarkan analisis dan pembahasan yang telah diuraikan dalam bab IV dapat disimpulkan, bahwa buku teks siswa kelas V SD/MI Tema 2 Udara Bersih bagi Kesehatan kurikulum 2013 terbitan Kementerian Pendidikan dan Kebudayaan (2017) termasuk dalam kriteria sangat sesuai dengan perolehan persentase skor kelayakan pada standar isi adalah sebesar 93,05\%, kelayakan pada standar bahasa adalah sebesar 93,32\%, sedangkan kelayakan pada standar penyajian adalah sebesar $100 \%$.

\section{Saran}

Dari hasil penelitian yang telah dilakukan, diharapkan dapat memberikan sedikit sumbangan berupa pemikiran yang digunakan sebagai usaha untuk meningkatkan kemampuan dalam bidang pendidikan. Adapun saran yang dapat disumbangkan antara lain 1) Bagi penyusun Hendaknya meneliti kembali konsep-konsep yang disajikan pada buku teks dan memperbaiki kesalahan konsep yang ada agar pembaca lebih memahami apa yang dipelajari serta menambahkan contoh-contoh yang lebih bervariasi lagi; 2) Bagi pendidik Hendaknya meneliti kembali buku yang akan dipakai sebagai sumber belajar karena tidak jarang buku yang masih terdapat kesalahan serta hal-hal lain yang menunjang kualitas sajian materi dari suatu buku; 3) Bagi peserta didik Hendaknya memiliki sikap kritis dalam menyikapi sesuatu, jika menemukan konsep yang tidak jelas, kurang dipahami, dan membingungkan dari dalam buku teks yang dibacanya hendaknya segera menanyakan ahlinya/ pendidik atau dapat pula dengan mencari dan membandingkan dengan sumber lainnya; 4) Bagi penelitian selanjutnya Perlunya dilakukan penelitian lanjutan karena tentunya akan muncul permasalahan baru yang berbeda dari kajian pada penelitian ini. 


\section{DAFTAR PUSTAKA}

Arikunto,S. 2010. Prosedur Penelitian Suatu Pendekatan Praktik. Jakarta:Rineka Cipta.

BSNP. 2017.Instrumen Penilaian Buku Teks Pelajaran Pendidikan Dasar Menengah. Jakarta :Depdiknas..

Depdiknas. 2007. Pedoman Memilih Menyusun Bahan Ajar dan Teks Mata Pelajaran.Jakarta:BP.Mitra Usaha Indonesia.

Fraenkel,J.C, and Wallen, N.E. 2006. How to Design and Evaluate Research in Education. New York : Mc Graw Hill.inc.

Kemendikbud. 2013. Permendikbud No.81A tentang Implementasi kurikulum. Jakarta:Kementerian Pendidikan dan Kebudayaan.

Komariah, Aan, Satori, Djam'an. 2014. Metodologi Penelitian Kualitatif. Jakarta:PT Gramedia. 